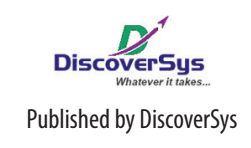

Published by DiscoverSys

\section{Barriers for people who inject drug (PWID) to access voluntary counselling and testing (VCT) at the health centres in East Lombok}

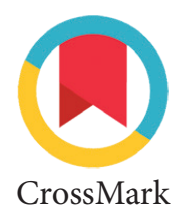

\author{
Dany Karmila, ${ }^{1 *}$ Pande Putu Januraga, ${ }^{1,2}$ Ni Wayan Septarini ${ }^{1,2}$
}

\section{ABSTRACT}

Background and purpose: Utilisation of voluntary counselling and testing (VCT) by people who inject drug (PWID) in East Lombok is low. This study aims to explore barriers for PWID to access VCT service from community health centres in East Lombok, West Nusa Tenggara.

Methods: A qualitative study was conducted in East Lombok. Data were collected using in-depth interviews. Nine participats were purposively selected consisted of five HIV negative PWID who repeatedly tested for HIV, one non-governmental organization official, one field worker, one VCT counsellor and one medical doctor. Data were inductively analysed.

Results: This study found that PWID preferred to use mobile VCT rather than VCT at health centres because of scared of getting caught by police. They also felt uncomfortable of using VCT service at the health centres due to stigma and discrimination. In addition, lack of human resources at the health centre was also found to be a significant barrier. This led to increased workload thus limited attention was given to quality of VCT service.

Conclusions: Barriers to access VCT service at the health centre include high stigma and discrimination from health provider and living arrangements of PWID. To improve VCT access for PWID, effective collaboration between health centres, private health institutions and village cadres are required.
${ }^{1}$ Public Health Postgraduate Program Udayana University, ${ }^{2} S$ chool of Public Health Faculty of Medicine Udayana University

*Correspondence to: Dany Karmila, Public Health Postgraduate Program Udayana University milakardia@yahoo.com

Keywords: qualitative study, HIV, voluntary counselling and testing, IDU, PWID, East Lombok Cite This Article: Karmila, D., Januraga, P.P., Septarini, N.W. 2017. Barriers for people who inject drug (PWID) to access voluntary counselling and testing (VCT) at the health centres in East Lombok. Public Health and Preventive Medicine Archive 5(1): 24-27. D01:10.15562/phpma.v5i1.37

\section{INTRODUCTION}

Human Immunodeficiency Virus and Acquired Immunodeficiency Syndrom (HIV-AIDS) is one among many global health problems. The HIV epidemic in Indonesia is considered as a concentrated epidemic with a prevalence of more than $5 \%$ among key population such as men who have sex with men (MSM), sex workers, transgender and people who inject drug (PWID). The majority of HIV cases were found among productive aged group. ${ }^{1}$

One of the provinces with increasing trend of HIV prevalence among high risk groups is West Nusa Tenggara. In 2014 there were $574 \mathrm{HIV}$ and AIDS cases with 379 died cases reported in the same year. ${ }^{2,3}$

One of the strategies implemented to prevent new infection and death is increasing the coverage of testing among high risk groups including PWID. Data from East Lombok District AIDS Commission showed that the utilization of VCT service at the health centre among PWID was low. For example, within the last few months only one or two PWID accessed VCT service at the health centre. ${ }^{4}$ In order to improve VCT coverage among PWID, health centres run a mobile VCT service at 'IDUs hotspot'. Given the nature of mobile service, providers did not comprehensively deliver pre and post test counselling to PWID. As a result, there is possibility for PWID to not having comprehensive knowledge on the importance of HIV testing and treatment, also due to technical problem in many cases, the test results could not be provided immediately to PWID. ${ }^{4}$ It is critical to encourage PWID to utilize VCT service at the health centre rather than the mobile VCT. ${ }^{5,6,7}$ This study aims to explore barriers to access VCT service at the health centre among PWID in East Lombok.

\section{METHODS}

A qualitative study with inductive inquiry was conducted in East Lombok District. In-depth interviews were conducted with nine participants who purposively selected in consultation with a local non-governmental organization/NGO. Participants consisted of five HIV negative PWID who repeatedly accessed VCT service, one NGO official, one field worker, one VCT counsellor, and one medical doctor. The study was conducted from March to May 2016.

In-depth interview was aimed to explore barriers to access VCT service at the health centres from the PWID perspective. Prior to interview, every participant was provided participant information sheet and informed consent was obtained. Data 
were inductively analysed by reading the scripts repeatedly and considering meanings presented by the texts.

The Planned Behaviour Theory was used to unpack the barriers for PWID to access VCT service at the health centre. This theory describes that barriers to access VCT service at the health centre are influenced by PWID perceived barriers which may originated from their norms or belief systems. ${ }^{8}$

Meanings were identified through indexing several codes to generate several categories. All codes were merged into three categories and were use to guide the discussion or to answer the study objectives. In order to improve data quality, triangulation of data sources, peer debriefing and literature comparison were conducted. ${ }^{9,10,11}$ The study protocol has been approved by Human Research Ethics Committee of Kerti Praja Foundation, Denpasar.

\section{Findings and Discussion}

Barriers for PWID to access VCT service at the health centres were rooted in experiences of and motivations to utilizing the service. Until now, very limited PWID actually utilized VCT service at the health centre. They preferred to access the mobile VCT service. In addition, they also have low motivation to access VCT service at the health centre. These are elaborated below.

\section{Barriers from the PWID Perspective}

PWID with HIV negative status who repeatedly access VCT service preferred to use mobile VCT than the service provided at the health centres. Some participants only accessed mobile VCT but never visited health centres for HIV testing. The following quotes illustrate this situation.

"mobile at my friend house, well [we] call our friends to gather there... then [our] blood were taken"

(VCT3, 23 years old)

"II was invited by my friend to attend a health education at [their] house"

(VCT2, 23 years old)

The NGO staff also echoed similar view by stating that mobile VCT is more favorable than VCT at the health centre. A field worker also stated that PWID are more comfortable accessing mobile VCT since they do not have to be at the health centres or meet up with new people which make them uncomfortable. This can be seen in the following quote:
"Eeeee from 2012... our friends [PWID] prefer mobile [VCT]..."

(NGO Staff, 34 years old)

A field worker also stated that PWID are afraid to access VCT service at the health centre because they might be get caught by police if they were at the health centre as can be seen in the following quote:

"Our friends [PWID]... they like mobile [VCT] because it is more convenient for them and more comfortable as they do not have to go the health centre. [they] are afraid as well if something happen at the health centre like get caught by police..."

(Field worker, 36 years old)

This study found that PWID with negative HIV status accessed mobile VCT more often than VCT at the health centre. In-depth interviews revealed that mobile VCT is more favorable among PWID. This preference is influenced by their past experiences when accessing VCT service at the health centre. They feel uncomfortable at the health centre because of the general health staff attitudes toward them, they have to face new people, and they also feel unsafe at the health centre as they might be caught by police if they were at the health centre. There is a suspicion among participants that the health centres joined with the police department to catch them. Furthermore, motivations of PWID to access VCT service at the health centre is low. It might be a result of lack of internal motivation from them and also limited support systems available to encourage them to access VCT service at the health centre. Other study found that external support from relatives or friends can improve utilization of VCT service. ${ }^{12}$

Mobile VCT in this study area is organized by community health centres in collaboration with local NGO. Local NGO is tasked to invite PWID and to prepare the location. The community health centres will come to a designated place. This strategy allows greater VCT coverage among PWID. ${ }^{4,6}$ Mobile VCT eases the access to HIV testing for PWID who live far out from the health centres and allows greater HIV testing coverage among PWID. ${ }^{5}$

This study found that PWID experienced stigma from health providers at the community health centres. It can be explained that general health staff are not well-exposed with HIV information leading to fear and moralizing people with HIV. They often associated people living with HIV as being immoral 
and they acquired HIV because they do not obey to religion and local values. In addition, posters on HIV and AIDS placed at the health centres also enhance fear among PWID to access VCT service at the health centre. A study conducted in primary health care settings at Llorin-Nigeria found that as many as $87.7 \%$ of general health staff were afraid of contracting HIV which leads to stigma and discrimination. ${ }^{13}$

PWID also experience stigma and discrimination from communities around their home. Local NGO staff explained that PWID are mindful that their families were disappointed. As a result, they receive little supports from their families. Furthermore, existing beliefs in the local communities that drug users cannot be cured especially when they infected with HIV also perpetuate this stigma and discrimination. ${ }^{8,14,15}$

"For stigma and discrimination... often faced by new PWID. It mainly comes first from families and second from their surroundings".

(NGO staff, 34 years old)

Other study has also found that social rejection leads to a low service coverage. In order to improve service utilization among PWID, a safe, comfortable and conducive environment should be provided. This requires partnership between governments, district and village officials, health cadres and community leaders to improve coverage of HIV education program and to ensure the stigma reduction programs were in place. ${ }^{16}$

\section{Barriers from health provider}

The availability of health human resources is a key barrier for implementing VCT service at the health centre. As a result, the VCT staff are also responsible for other health programs. This means that they must split their attention not only to VCT program but also to other health programs. ${ }^{4}$

The availability of physician during the service provision is also viewed by health providers as another key barrier. PWID are more reluctant to open their HIV status or to access HIV-related services if no physician is available. In fact, physician is not always available at the health centre as explained by the local NGO staff. This can be seen in the following quote:

"The doctor is not available, so our friends [PWID] who have a health problem are unable to see the doctor"

(Local NGO, 34 years old)

This study found that medical doctor is not always available at the VCT clinic due to limited number of doctors available at the health centre. In addition, doctors might also be overburdened with other health programs. Even though VCT counsellor and laboratorium analyst are always available at the VCT clinic, PWID expect a physician to serve them as they are more comfortable to discuss their health problems with physician. They also believe that physician will help them to build their self-esteem too.

This study also found that opening time for VCT service at the health centre is also a significant barrier. VCT service at the health centre follows the opening and closing time of the health centre, which is not convenient for PWID. They are working in the morning until late afternoon. If PWID wish to access VCT service at the health centre, they must ask for a permission from their employer which is not always an easy thing. The majority of VCT staff are also contractual position and almost impossible for them to provide extra hour service without permission from the head of health centre. Opening and closing time at the health centre are bound to the health centre policy and it is hardly changed. This can be seen in the following quote:

"For me... It is probably more related with time. VCT service usually open at 7.30 until 12 am. After that the doctor is probably unavailable, also people at the VCT clinic is often unavailable after 12 am".

(VCT5, 27 years old)

Furthermore, medical doctor at the health centre explained that PWID still experience stigma from the general health staff. Even though health education on HIV and AIDS has been conducted at the health centres, some health providers are still judgemental about PWID and fear about HIV and AIDS. This can be seen in the following quote:

"Yeah there is still a high stigma from yeah health providers, for example if the health staff knew the patient who went to VCT clinic... They start to freak out..."

(Physician, 47 years old)

This study revealed that PWID still experienced stigma and discrimination from general health staff at community health centres. Stigma and discrimination inhibit PWID to access HIV services at the health centre thus can reduce the coverage of HIV services among key population. This might be associated to the lack of comprehensive HIV and AIDS knowledge among health providers and moral judgements attached to PWID. These further perpetuate stigma and discrimination against PWID. ${ }^{17}$ 


\section{CONCLUSION}

Barriers for PWID to access VCT service at the health centre are both from supply and demand sides leading to a low coverage of HIV services among this key population. These barriers include high stigma and discrimination from health provider and living arrangements of PWID. To improve VCT access for PWID, effective collaboration between health centres, private health institutions and village cadres are required.

\section{ACKNOWLEDGEMENT}

We would like to thank all participants and stakeholders who had participated in and supported this study. Also, I would like to thank the East Lombok District Government, West Nusa Tenggara for allowing this study to be conducted.

\section{REFERENCE LISTS}

1. Ministry of Health of Indonesia. United nations programme on hiv and aids. 2012; 1-10.

2. Ministry of Health of Indonesia. Statistik Kasus HIV/ AIDS di Indonesia Dilapor s/d September 2014 [Statistic of HIV/AIDS Cases in Indonesia Reported Up to September 2014]; 2014; 794-796

3. Provincial AIDS Commission of West Nusa Tenggara. (n.d). Renstra Dikes NTB [Strategic Planning of Health Office of West Nusa Tenggara].

4. District AIDS Commission of East Lombok. (n.d). Klinik VCT Kabupaten Lombok Timur [VCT Clinic of East Lombok District].

5. National AIDS Commission of Indonesia. Survey Cepat Perilaku Pengguna Napza Suntik [Quick Behavior Survey among PWID] http:// www.kebijakanaidsindonesia.net/ $\mathrm{id} /$ beranda/28-pengantar introduction/108-strategic-useof-anti-retro-viral. Retrieved 28 September 2015.

6. Sari AW (n.d). Faktor - faktor yang Berhubungan dengan Niat Ibu Hamil untuk Memanfaatkan Layanan VCT di Wilayah Kerja Puskesmas Cipuitat Kota Tangerang Selatan Provinsi Banten [Factors associated to willingness of pregnant women to access VCT in Ciputat Community Health Centre, West Tangerang City - Banten Province]
7. Ministry of Health of Indonesia. Pedoman Pelayanan VCT [VCT Implementation Guideline]; 2011.

8. Notoatmodjo, Soekidjo. Promosi kesehatan dan Perilaku Kesehatan [Health promotion and health behavior]. Jakarta : Rineka cipta; 2012.

9. Bungin. Analisis Data Penelitian Kualitatif [Qualitative Data Analysis]; 2012.

10. Ahmadi. Metodologi Penelitian Kualitatif [Qualitative Research Methodology]; 2014.

11. Thomas DR. A General Inductive Approach for Analyzing Qualitative Evaluation Data. Am J Eval; 2006; 27: 237-246

12. Sitepu. Pengaruh Pengetahuan Persepsi dan Motivasi PSK terhadap Pemanfaatan Layanan Klinik IMS/HIV-AIDS di Puskesmas Bandar Baru [Effects of knowledge, attitudes and motivations sex workers on utilisation of STI and HIV/AIDS clinic at Bandar Baru Community Health Centre]. Research Article

13. Holzemer WL, Uys LR. Managing AIDS Stigma https:// www.scribd.com/doc/171623951/Teori-Precede. 2004. Retrieved 24 January 2016)

14. Pisani E, Dadun, Purwa, K., Sucahya, Kamil, O., Jawan, S. Estimating the number of drug injectors in Indonesia. International Journal of Drug Policy; 2014. http://pustaka. unpad.ac.id/wp-StigmaO dhapdf. Retrieved 15 November 2015.

15. Moyer LB. Barriers and missed opportunities to HIV testing among injection drug users in two Mexico--US border cities; 2008. Retrieved November 12, 2015

16. Wicaksana. Pengetahuan tentang HIV / AIDS dan Voluntary Counseling and Testing (VCT), Kesiapan Mental dan Perilaku Pemeriksaan di Klinik VCT pada Para Mitra Pengguna Obat dengan Jarum Suntik di Surakarta [Knowledge on HIV/AIDS and VCT, mental state and service uptake at VCT clinic among PWID partner in Surakarta]; 2010.

17. Purwaningsih. Analisis Faktor Pemanfaatan VCT Pada Orang Risiko Tinggi HIV / AIDS (Analysis of factors associated to VCT utilisation among high risk groups]; 2011.

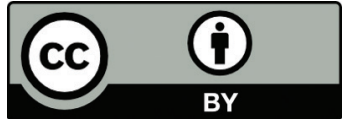

This work is licensed under a Creative Commons Attribution 